\title{
Introduction of Reforms
}

\section{Agayev Fahri*}

The Association of Alberta Agriculture Fieldmen, Alberta, Canada

*Corresponding author: Fahri A, Vice-president, The Association of Alberta Agriculture Fieldmen, Alberta, Canada, Tel: + 994502335544; E-mail: fahriagayev@yandex.ru

Received date: February 23, 2017, Accepted date: April 28, 2017, Published date: May 03, 2017

Copyright: (c) 2017 Fahri A. This is an open-access article distributed under the terms of the Creative Commons Attribution License, which permits unrestricted use, distribution, and reproduction in any medium, provided the original author and source are credited.

\section{Introduction}

\section{Five Mistakes in Carrying out Reforms in the Company}

There is a period in the life of each company when shareholders and owners understand that there is a need to introduce changes and reforms. Reasons for this may be different: global crises that need to be immediately reacted to, changing market conditions and macroeconomics conditions, strengthening of competition, introduction of new technologies, the need to reduce costs in order to increase the competitiveness of the company in the long term, introduction of new products to market and etc.

Only the fact of competition in the market and the fight for His Majesty the Consumer is enough reason to force companies to be constantly "in shape".

There are few simple rules for the introduction and implementation of reforms and their long-term success: support and direct participation of top management, providing information on the purpose and nature of the reforms to staff, forming a powerful team of reformers. However, improper performance of these rules brings to partial success of planned changes. Failures in the implementation of reforms are due to different but related reasons.

For the last 15 years I worked in different top managerial positions and in many cases one of my most important responsibilities was the introduction and implementation of reforms in the company. During these years a faced different cases, situations, was successful and unsuccessful, had to use my psychological power in order to overcome problems, stepping back and ready to loose battle in order to win war.

Having this broad experience I tried to systemize main mistakes that are made in the way of making reforms in companies.

\section{The lack of leadership with example}

The core of the problem: The senior management is not involved in reforms or passively participates.

Reforms initiated by and always start at the highest level. Senior managers of the company should not be just at the front line of changes - they have to be ahead of these changes. If after the first shortterm success top management switches their attention and energy to other projects, then the likelihood of a slow decrease of concentration of middle management to reforms is high.

\section{Ignoring line staff and middle management}

The core of the problem: the detailed information about the reforms, their essence and targets are not given to middle management and employees.
Senior management being in their comfortable offices can prepare high quality standards, instructions, write down business processes, but if they are not brought in an accessible form to the staff, the reforms will fail. Regardless of how economically justified, theoretically correct and effective looking solutions and decisions are taken in the offices of the seniors, they should not forget that actually all changes are made by employees. And all professionally written standards of customer service and care will be ineffective until they are accepted by staff who will implement these rules.

The most genius programs, which promise inevitable success on paper, may still remain on paper if they do not capture the minds and souls of employees.

Boris Groysberg, a professor at Harvard Business School in his research on intercompany communications, cites company Hindustan Petroleum Corporation, in which the "change of vision was brought to the attention of 11,000 employees in groups of 20 people, and the process took several years."

\section{Absence of reform team}

The core of the problem: the powerful group of people who can lead the processes of changes

Together with the initiative by and personal participation of top managers there should be also a team of reformers, committed to new ideas. While carrying out reforms in the company, management should not forget that we are talking about changing the habits, work style, routine of people to which they are used to - and this is exactly what meets resistance, because any change means going beyond the usual comfort zone.

The team of reformers, collected from various departments and fields of the company will be much more successful in overcoming the resistance and devoting their time and energy for individual persuasion of main "resisters".

\section{The presence of "conservatives" team}

The core of the problem: People who are not inclined to reforms, are the adherents of the classic style of management and main participants of the resistance to changes.

In addition to their own resistance and blocking the changes, "conservatives" also have a negative impact on the overall ongoing work, motivation and attitude of the people in the company. It is a vicious circle: the team is under the influence of main "conservatives", and top management of company is afraid of losing experienced and valuable experts. As a result of this stalemate condition middle management and staff conclude that the top management is not so ready for reforms and the speed of changes slows down. 
Page 2 of 2

In some cases, the company's senior management starts reforms, but at sight of first short-term problems steps back or reduce the volume of initial support.

In this case, the Conservatives use this situation to weaken the position of the reformers. The presence of one of conservators in a team of reformers will strengthen the position of reform supporters. After conservatives are convinced that the general objective of the team is to make improvements in the company and there is no purpose to get rid of some of them, the Conservatives will gradually get used to the changes and accept them.

\section{Absence of system to fix and strengthen the changes}

The core of the problem: Progress in changes is not fixed in the corporate culture.

Short-term results are presented and perceived as a victory. The difference between short-term and long-term positive results as huge as between the battle and the war. You can win the battle but lose the war.
As long as the changes do not become the standard and the usual working style at all levels in the company, it will be too early to talk about long-term success.

People by nature are strongly attached to their habits and sometimes demonstrate strong resistance to all kinds of changes that force them to come out of their comfort zone. This is the reason why often we observe cases where for some time after the beginning of the reforms, people act according to the new standards, but in view of the fact that new working style and activities, procedures and processes is not entrenched, people return to their previous approach to work.

Even if there is not written corporate culture in the company, there is unwritten corporate culture which is in some cases much stronger that official one. People are bound with unofficial rules and standards and there should be sustainable, continuous work with new standards.

- Introduction and implementation of reforms is long-term process which should be carried by top management with their personal, direct and very close participation being careful not to accept the battles instead of wars. 